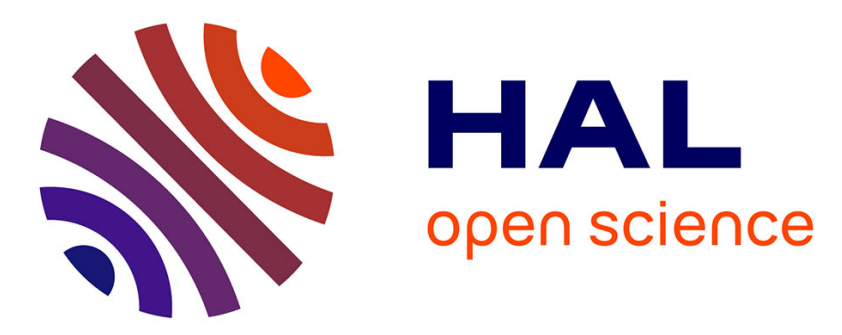

\title{
Palladium Isolation and Purification from Nitrate Media: Efficient Process Based on Malonamides
}

Régis Mastretta, Rémi Poirot, Damien Bourgeois, Daniel Meyer

\section{To cite this version:}

Régis Mastretta, Rémi Poirot, Damien Bourgeois, Daniel Meyer. Palladium Isolation and Purification from Nitrate Media: Efficient Process Based on Malonamides. Solvent Extraction and Ion Exchange, 2019, 37 (2), pp.140-156. 10.1080/07366299.2019.1630073 . hal-02385602

\section{HAL Id: hal-02385602 \\ https://hal.umontpellier.fr/hal-02385602}

Submitted on 19 Nov 2020

HAL is a multi-disciplinary open access archive for the deposit and dissemination of scientific research documents, whether they are published or not. The documents may come from teaching and research institutions in France or abroad, or from public or private research centers.
L'archive ouverte pluridisciplinaire HAL, est destinée au dépôt et à la diffusion de documents scientifiques de niveau recherche, publiés ou non, émanant des établissements d'enseignement et de recherche français ou étrangers, des laboratoires publics ou privés. 
Palladium isolation and purification from nitrate media: efficient process based on malonamides

\author{
Régis Mastretta, Rémi Poirot, Damien Bourgeois," Daniel Meyer \\ Institut de Chimie Séparative de Marcoule, \\ UMR 5257 CEA/CNRS/UM2/ENSCM \\ BP 17171, 30207 Bagnols-sur-Cèze, France
}

Keywords: palladium, iron, solvent extraction, malonamide, waste reprocessing. 
Abstract: Solvents based on malonamides have been described to be very efficient and selective for liquid-liquid extraction of $\mathrm{Pd}(\mathrm{II})$ from nitrate media. The present study details the possibility to selectively extract $\mathrm{Pd}(\mathrm{II})$ over common metallic cations, $\mathrm{Cu}(\mathrm{II})$, $\mathrm{Ni}(\mathrm{II}), \quad \mathrm{Co}(\mathrm{II}), \quad \mathrm{Zn}(\mathrm{II}), \quad \mathrm{Nd}(\mathrm{III}), \quad \mathrm{Fe}(\mathrm{III}) \quad$ and $\mathrm{Al}(\mathrm{III}) \quad$ using $\quad N, N^{\prime}$-dimethyl, $N, N^{\prime}$ dibutyltetradecylmalonamide (DMDBTDMA) in toluene. The lowest selectivity was obtained considering $\mathrm{Fe}(\mathrm{III})$ and $\mathrm{Nd}(\mathrm{III})$, the extraction of all other cations being negligible. Pd(II) distribution and selectivity regarding Fe(III) have been fine-tuned using the aqueous $\mathrm{HNO}_{3}$ concentration as the sole parameter, so that extraction, scrubbing and stripping steps can be simply designed without the need for other specific metal chelating reagents and/or aqueous media, and without the extensive generation of aqueous effluents. DMDBTDMA was also benchmarked with other classical Pd(II) extractants such as tributylphosphate (TBP), dihexylsulfide (DHS), tetraoctyl diglycolamide (TODGA) and bis(2-ethylhexyl)sulfoxide (BESO) in toluene and in $n$-heptane. Overall, this study reveals that malonamides are very well positioned and should be considered for further processing of aqueous nitrate wastes containing Pd contaminated with common base metals.

\section{*Corresponding author:}

Tel.: +33 (0)4 663394 92; fax: +33 (0)4 667976 11;

e-mail: damien.bourgeois@cea.fr

Running head: Palladium isolation and purification from nitrate media 


\section{INTRODUCTION}

Palladium (Pd) is a precious metal which has been the focus of extensive efforts for an efficient recovery from various wastes [1-4]. Generally, leaching of precious metals from wastes such as end of use automotive catalysts or shredded electronic scraps is performed in aqua regia, a mixture of nitric and chlorhydric acid, but there is also a peculiar interest on leaching with sole nitric acid $\left(\mathrm{HNO}_{3}\right)$ as $\mathrm{Pd}$ is highly soluble in this medium, along with silver $(\mathrm{Ag})$, on the contrary to gold $(\mathrm{Au})$ and platinum $(\mathrm{Pt})[5,6]$. As a consequence, various industrial effluents containing $\mathrm{Pd}$ in $\mathrm{HNO}_{3}$ with variable amount of chloride ions have been described [7,8]. Furthermore, the reprocessing of electronic scrap often involves a first leaching step in concentrated $\mathrm{HNO}_{3}$ alone, to remove most of base metals and enable a more efficient subsequent Au leaching in aqua regia $[9,10]$. Most Ag is lost during this first $\mathrm{HNO}_{3}$ leaching, and the outcome of Pd is not clear: although it is likely that $\mathrm{Pd}$ is also contained in these solutions, no $\mathrm{Pd}$ content has been reported to our knowledge. Altogether, there is a need for robust solutions to process $\mathrm{HNO}_{3}$ streams containing Pd more or less contaminated with other base metals such as $\mathrm{Fe}, \mathrm{Al}, \mathrm{Cu}, \mathrm{Ni}$, Zn... These streams may contain Pd at relatively high concentrations (up to several g/L), or at low concentrations (10-250 mg/L) according to their origin [11-16]. Recovery of the Pd from these solutions has been envisioned according to different techniques, such as precipitation [17], solvent extraction [18], solvent impregnated [19] or chelating resins [20,21]. Recently, we reported that $N, N^{\prime}$-dimethyl, $N, N$ '-dioctylhexylethoxymalonamide (DMDOHEMA) is an unexpectedly good candidate to extract Pd from nitrate media, as the 1,3-propanediamide (malonamide) moiety presents the adequate geometry to efficiently chelate the $\mathrm{Pd}(\mathrm{II})$ cation [22]. Also, we demonstrated that although this molecule was initially designed to purify lanthanides form minor actinides with solvent 
extraction, its selectivity for $\mathrm{Pd}(\mathrm{II})$ regarding $\mathrm{Nd}(\mathrm{III})$ can be tuned according to the diluent and/or the $\mathrm{HNO}_{3}$ content of the aqueous phase [23]. Selectivity factors $\left(\mathrm{S}_{\mathrm{Pd} / \mathrm{Nd}}=\right.$ DPd/ DNd) exceeding 20 with solvents based on DMDOHEMA at concentrations ranging from 0.3 to $0.6 \mathrm{M}$ have been obtained, either at low acidity in aliphatic diluents $(n$ heptane), or at high acidity in aromatic diluents (toluene). This selectivity is the result of the control of the aggregation of the organic phase, and does not rely on modification of the aqueous speciation of the cations (with addition of specific chelating agents for instance). Furthermore, Pd distribution coefficient (DPd) lies around 10, without optimization, suggesting that both efficient extraction and easy stripping of $\mathrm{Pd}$ can be envisioned with this system. Thus, we decided to explore whether it is possible to exploit these results to develop a straightforward process for selective Pd recovery from nitrate aqueous solutions based on a malonamide solvent.

The purpose of this article is to present in detail the design of a malonamide based solvent, that enables selective $\mathrm{Pd}(\mathrm{II})$ extraction, in the presence of base metals, such as $\mathrm{Fe}(\mathrm{III}), \mathrm{Al}(\mathrm{III}), \mathrm{Zn}(\mathrm{II}), \mathrm{Cu}(\mathrm{II}), \mathrm{Ni}(\mathrm{II}), \mathrm{Co}(\mathrm{II})$ and lanthanides, especially $\mathrm{Nd}(\mathrm{III})$. As previous reports on closely related $N, N$ '-tetrasubstituted malonamides, bearing or not an alkyl chain on the central carbon atom, reported that Fe(III) can be very efficiently extracted [24-26], we focused part of our study on the $\mathrm{Pd}(\mathrm{II}) / \mathrm{Fe}(\mathrm{III})$ separation. We also explored the scope and limitations of this solvent, with regard to some other potentially usable solvents based on commercially available extractants, tributylphosphate (TBP), dihexylsulfide (DHS), and bis(2-ethylhexyl)sulfoxide (BESO). Finally, we modelled a possible process with $\mathrm{Fe}(\mathrm{III})$ scrubbing and $\mathrm{Pd}(\mathrm{II})$ stripping sections employing only diluted $\mathrm{HNO}_{3}$ aqueous solutions, ie without the need for changing aqueous media nor specific metal chelating anions. 


\section{EXPERIMENTAL}

\section{Chemical Reagents}

DMDOHEMA and $N, N^{\prime}$-dimethyl, $N, N^{\prime}$-dibutyltetradecylmalonamide (DMDBTDMA)

(Figure 1) were kindly provided by the CEA, France (DEN/MAR/DRCP). Production was performed by Pharmasynthèse (former Panchim), France, purity is $98 \%$ and the products were used without further purification. Palladium(II) nitrate hydrate $\left(\mathrm{Pd}\left(\mathrm{NO}_{3}\right)_{2} \cdot \mathrm{xH}_{2} \mathrm{O}\right.$, ca. $\left.40 \% \mathrm{Pd}, 99.9 \% \mathrm{Pd}\right)$, Iron(III) nitrate nonahydrate $\left(\mathrm{Fe}\left(\mathrm{NO}_{3}\right)_{3} \cdot 9 \mathrm{H}_{2} \mathrm{O}\right.$, $98+\% \mathrm{Fe})$, Copper(II) nitrate trihydrate $\left(\mathrm{Cu}\left(\mathrm{NO}_{3}\right)_{2} .3 \mathrm{H}_{2} \mathrm{O}, 99.5 \% \mathrm{Cu}\right)$, Aluminium(III)

nitrate nonahydrate $\left(\mathrm{Al}\left(\mathrm{NO}_{3}\right)_{3} \cdot 9 \mathrm{H}_{2} \mathrm{O}, 98+\% \mathrm{Al}\right)$, Neodymium(III) nitrate hexahydrate $\left(\mathrm{Nd}\left(\mathrm{NO}_{3}\right)_{3} \cdot 6 \mathrm{H}_{2} \mathrm{O}, 99.9+\% \mathrm{Nd}\right)$, Cobalt(II) nitrate hexahydrate $\left(\mathrm{Co}\left(\mathrm{NO}_{3}\right)_{2} \cdot 6 \mathrm{H}_{2} \mathrm{O}, 99 \%\right.$ Co), Nickel(II) nitrate hexahydrate $\left(\mathrm{Ni}\left(\mathrm{NO}_{3}\right)_{2} \cdot 6 \mathrm{H}_{2} \mathrm{O}, 99.9 \% \mathrm{Ni}\right)$ and Zinc(II) nitrate hexahydrate $\left(\mathrm{Zn}\left(\mathrm{NO}_{3}\right)_{2} \cdot 6 \mathrm{H}_{2} \mathrm{O}, 98+\% \mathrm{Zn}\right)$ were purchased from Strem. Organic diluents ( $n$-heptane, toluene, chloroform), concentrated hydrochloric and concentrated nitric acids were purchased from Carlo Erba reagents. Lithium nitrate $\left(\mathrm{LiNO}_{3}\right)$, TBP $(97 \%)$ and DHS (95\%) were purchased from Sigma-Aldrich, BESO (98\%) from Alfa Aesar. All reagents were used without further purification.

\section{Solvent Extraction}

Extractions were performed in vials with an organic phase containing extracting molecule and diluent and an aqueous $\mathrm{HNO}_{3}$ solution containing a mixture of metallic cations in known concentrations. Aqueous phases were prepared by dilution of stock solutions of each metallic cation $(5 \mathrm{~g} / \mathrm{L})$ into a $6 \mathrm{M} \mathrm{HNO}_{3}$ aqueous solution, prepared by dissolution of the corresponding salt into a $6 \mathrm{M} \mathrm{HNO}_{3}$ aqueous solution, optional addition of $\mathrm{LiNO}_{3}$, and the final $\mathrm{HNO}_{3}$ concentration was adjusted with deionized water. Organic phases were 
prepared by dilution of DMDOHEMA, DMDBTDMA, TBP, DHS, BESO, or TODGA in the appropriate diluent and were pre-equilibrated with the adequate aqueous phase containing all reagents except the metallic cations to study. Unless otherwise noticed in the text, the volume of the organic phase was $1 \mathrm{~mL}$, and the volume of the aqueous phase was chosen according to the $\mathrm{A} / \mathrm{O}$ ratio detailed in the text. The two phases were vigorously shaken at $1000 \mathrm{rpm}$ with an IKA-Vibrax VXR basic shaker in a $20-22^{\circ} \mathrm{C}$ environment. The tubes were removed and centrifuged for 5 min or until complete phase separation and the phases were separated, and $500 \mu \mathrm{L}$ of each phase were taken for analysis.

The aliquot of the aqueous phase was directly diluted into a $2 \% \mathrm{HNO}_{3} / \mathrm{HCl}$ aqueous solution (90/10). Metals contained in the aliquot of the organic phase were back-extracted with $800 \mu \mathrm{L}$ of an aqueous $0.1 \mathrm{M}$ thiourea solution at $20-22^{\circ} \mathrm{C}$ for $1 \mathrm{~h}$. Both phases were separated, and $500 \mu \mathrm{L}$ of the resulting aqueous solution were taken and diluted into a $2 \%$ $\mathrm{HNO}_{3} / \mathrm{HCl}$ aqueous solution (90/10). Preliminary studies showed that $\mathrm{Pd}(\mathrm{II})$ as well as other metals were totally stripped with this process, and that no metal precipitation occurred until analysis. Dilution factors were chosen so that metal concentrations are not above $20 \mathrm{mg} / \mathrm{L}$, with a minimum 10 fold dilution to avoid matrix effects. Concentrations of each metal in both aqueous phases (extraction and stripping phases) were determined by inductively coupled plasma atomic emission spectroscopy (ICP/AES, SPECTRO ARCOS ICP Spectrometer, AMETEK Materials Analysis). Standards at $0 \mathrm{mg} / \mathrm{L} ; 0,5$ $\mathrm{mg} / \mathrm{L} ; 1 \mathrm{mg} / \mathrm{L} ; 5 \mathrm{mg} / \mathrm{L} ; 10 \mathrm{mg} / \mathrm{L}$ and $15 \mathrm{mg} / \mathrm{L}$ were prepared by dilution of $1,00 \mathrm{~g} / \mathrm{L}$ solutions (SCP Science) into a $2 \% \quad \mathrm{HNO}_{3} / \mathrm{HCl}$ aqueous solution (90/10). Given concentrations are calculated as the means of three replicates on three different wavelengths for each metal; relative standard deviations were determined and lie between 
1 and $4 \%$. Quantification limits were determined for each metal from the background equivalent concentration (BEC) calculated by the spectrometer for each optical line and are summarized below (Table 1).

5 Concentrations of each metal after extraction experiments were compared to the concentrations of same metal in the initial aqueous phase before contacting the aqueous layer with the organic layer. The distribution ratio, D, was calculated for each metal as the ratio at equilibrium between the total concentration of said metal in the organic phase and the total concentration of said metal in the aqueous phase. Confidence intervals were determined taking into account the error of the spectrometer and the precision of the materials employed for dilution, and relative errors were found to lie between 5 and $10 \%$. Unless otherwise stated in this article, all results show a total mass balance (determined assuming that the volume change of each phase can be neglected) in each metal comprised between 95 and $105 \%$ of the initial metal load in the aqueous phase.

\section{$\mathrm{HNO}_{3}$ concentration determination}

Concentration of $\mathrm{HNO}_{3}$ in both aqueous and organic phases was obtained after potentiometric titration using a Mettler DL77 Titrator equipped with a combined glass electrode for $\mathrm{pH}$ measurements. The aqueous phase was directly analyzed, the organic phase was beforehand diluted with ethanol ( $5 \mathrm{~mL}$ for $100 \mu \mathrm{L}$ of organic phase), then water $(15 \mathrm{~mL})$. Acid-base titration was carried out using 0,010 $\mathrm{M}$ aqueous $\mathrm{NaOH} . \mathrm{HNO}_{3}$ distribution ratio $\left(\mathrm{DHNO}_{3}\right)$ was then obtained after pre-equilibration of solvent in different conditions as the ratio at equilibrium between the $\mathrm{HNO}_{3}$ concentration in the organic phase and the $\mathrm{HNO}_{3}$ concentration in the aqueous phase. 


\section{RESULTS AND DISCUSSION}

\section{Composition of solvent}

Following our fundamental studies related to the $\mathrm{Pd}(\mathrm{II}) / \mathrm{Nd}(\mathrm{III})$ separation $[22,23]$, we screened the extraction of several common metallic cations with DMDOHEMA in $n$ heptane in order to determine the scope of the selectivity of $\mathrm{Pd}(\mathrm{II})$ extraction with this malonamide (Figure 2). We focused on +II and +III cations regularly found in metallic wastes such as waste of electric and electronic equipment (WEEE), varying the DMDOHEMA concentration in the solvent, and the aqueous $\mathrm{HNO}_{3}$ concentration. Both parameters have a positive impact on metallic cations extraction, and a negative impact on $\mathrm{Pd} / \mathrm{Nd}$ selectivity $\left(\mathrm{S}_{\mathrm{Pd} / \mathrm{Nd}}\right)$. This negative impact on selectivity is principally due to the increase of organic phase aggregation induced by the $\mathrm{HNO}_{3}$ extracted from the aqueous phase. No noticeable extraction of $\mathrm{Cu}(\mathrm{II}), \mathrm{Ni}(\mathrm{II}), \mathrm{Co}(\mathrm{II}), \mathrm{Zn}(\mathrm{II})$ or $\mathrm{Al}(\mathrm{III})$ was found. The only other metallic cation extracted is $\mathrm{Fe}(\mathrm{III})$, only when the aqueous $\mathrm{HNO}_{3}$ concentration is important $\left(\left[\mathrm{HNO}_{3}\right]_{\mathrm{aq}} \geq 3 \mathrm{M}\right)$. Extraction yields of $\mathrm{Nd}(\mathrm{III})$ are always higher than those of $\mathrm{Fe}(\mathrm{III})$, except at $5 \mathrm{M}$ aqueous $\mathrm{HNO}_{3}$, thus $\mathrm{Nd}(\mathrm{III})$ can be employed as a reference cation in order to propose a selective solvent. $\mathrm{Pd}(\mathrm{II})$ extraction becomes significant either when DMDOHEMA concentration in the solvent is high or when aqueous nitric acid concentration is high (as long as $\left[\mathrm{HNO}_{3}\right]_{\mathrm{aq}}$ remains below $6 \mathrm{M}$, otherwise competitive $\mathrm{HNO}_{3}$ extraction leads to a drop in $\mathrm{Pd}(\mathrm{II})$ extraction [22]). As a consequence, there is a compromise to find between high selectivity and sufficient $\mathrm{Pd}$ distribution coefficient (Dpd). In our previous studies, we demonstrated that a ca. ten fold increase in $\mathrm{Pd} / \mathrm{Nd}$ selectivity can be obtained with toluene as a diluent [23]. This change in diluent is important to take into consideration, as with DMDOHEMA in $n$-heptane, we previously reported that DPd above 10 are only obtained when $\mathrm{Nd}(\mathrm{III})$ is also significantly 
extracted (Table 2). Also, organic phase splitting can arise when Pd(II) load in the solvent reaches 2,5 - $10 \mathrm{~g} / \mathrm{L}$ [22]. Latter splitting is due to the precipitation of a $\mathrm{Pd}(\mathrm{II})$ DMDOHEMA complex, fully soluble in toluene, so that no organic phase splitting was observed using this diluent. Using DMDOHEMA in toluene, it is thus possible to have both a DPd above 5 along with $S_{P d / N d}$ above 10, eg. using 0,3 M DMDOHEMA with a 4 $\mathrm{M}\left[\mathrm{HNO}_{3}\right]_{\mathrm{aq}}$ aqueous solution, or $0,4 \mathrm{M}$ DMDOHEMA with a $3 \mathrm{M}\left[\mathrm{HNO}_{3}\right]_{\mathrm{aq}}$ aqueous solution (Table 2).

DMDOHEMA has been chosen for the partitioning of trans-uranium elements from high level liquid waste in the reprocessing of spent nuclear fuel according to its affinity for both lanthanides(III) and actinides(III) [27]. The former malonamide reference [28], $N, N$ '-dimethyl, $N, N$ '-dibutyltetradecylmalonamide (DMDBTDMA, Figure 1), has been discarded in these studies, although it is easier to prepare (the central carbon atom chain does not need to be synthetized separately). This extracting molecule is also very stable in nitrate media [29]. As a consequence, we compared both malonamides with toluene as a diluent (Figure 3). As expected, Nd distribution ratios are lower with DMDBTDMA than with DMDOHEMA: at $5 \mathrm{M}\left[\mathrm{HNO}_{3}\right]_{\mathrm{aq}}$, DNd is 0,3 with DMDBTDMA and 0,7 with DMDOHEMA. More surprising is the increase in DPd: these were found about twice bigger with DMDBTDMA than with DMDOHEMA. Altogether, $\mathrm{S}_{\mathrm{Pd} / \mathrm{Nd}}$ are 4 times bigger with DMDBTDMA than with DMDOHEMA, especially in the conditions where $\mathrm{Pd}$ is well extracted, ie above $3 \mathrm{M}\left[\mathrm{HNO}_{3}\right]_{\mathrm{aq}}$. With DMDBTDMA in toluene, it is therefore possible to find adequate conditions for efficient $\mathrm{Pd}(\mathrm{II})$ extraction and separation from $\mathrm{Nd}(\mathrm{III})$, and as a consequence for other multivalent cations evaluated previously. 


\section{Modelling of counter-current process}

With the so gathered data, it is possible to model the behavior of each metal during extraction and back-extraction steps. Therefore, we devised a counter-current process based on a classical three steps sequence, extraction, scrubbing and stripping, to demonstrate the potential interest of the DMDBTDMA based solvent. Modelling was performed with the assumption that equilibrium is reached in each stage, and that both phases are always far from saturation, which was checked at the end of the process. The model is base on an initial $3 \mathrm{M} \mathrm{HNO}_{3}$ aqueous solution containing $100 \mathrm{mg} / \mathrm{L} \mathrm{Pd}(\mathrm{II})$ and $2000 \mathrm{mg} / \mathrm{L} \mathrm{Fe}(\mathrm{III})$, and 0,6 M DMDBTDMA in toluene. Each step was decomposed in six stages.

The Pd extraction step is easy to model as the aqueous $\mathrm{HNO}_{3}$ concentration remains constant all along the different stages. In the chosen conditions, with an aqueous to organic flow phase ration $(\mathrm{A} / \mathrm{O})$ of 5 , and previously determined DPd $=15,6$ and $\mathrm{DFe}=$ 0,32 , after the 6 stages, more than $99,9 \%$ of the $\mathrm{Pd}$ and $6,4 \%$ of the Fe are extracted (Figure 9). The extract contains then $500 \mathrm{mg} / \mathrm{L} \mathrm{Pd}$ and $640 \mathrm{mg} / \mathrm{L} \mathrm{Fe}$. The A/O ratio can be chosen according to the distribution coefficients in order to maximize Pd extraction yield and minimize Fe extraction yield; both can be exactly calculated after each stage according to equation (1), where $\mathrm{N}$ the stage number:

$$
\text { Yield }=\frac{D}{A / O} \cdot \frac{\left(\frac{D}{A / O}\right)^{N}-1}{\left(\frac{D}{A / O}\right)^{N+1}-1}
$$

The loss in Pd can be deduced and its expression simplified into equation (2) taking into account that $\left(\frac{D_{P d}}{A / O}\right)^{N+1} \gg 1$ :

$$
P d \text { loss } \approx \frac{1}{\left(\frac{D_{P d}}{A / o}\right)^{N}}
$$


And the amount of Fe extracted can also well be estimated with equation (3) as in this case $\left(\frac{D_{F e}}{A / O}\right)^{N+1} \ll 1:$

$$
\operatorname{Yield}(F e) \approx \frac{D_{F e}}{A / O}
$$

The Fe scrubbing step was then modelled following a two-stage operation. First of all, the $\mathrm{HNO}_{3}$ concentrations in organic and aqueous phases were determined for each stage according to the procedure presented beforehand, ie using the linear model determined for $\mathrm{DHNO}_{3}$. Then, from the aqueous $\mathrm{HNO}_{3}$ concentration at equilibrium in each stage, both DPd and DFe were deduced, and the concentrations of each metallic cation at equilibrium in each stage calculated consequently, taking into account mass balance. Overall Pd loss and Fe scrubbing yield are finally obtained through the comparison on input and output quantities. Different aqueous $\mathrm{HNO}_{3}$ solutions and various $\mathrm{O} / \mathrm{A}$ ratios were evaluated, and a good compromise consisted in the use of a 1,2 mol/L aqueous $\mathrm{HNO}_{3}$ solution with an O/A flow ratio of 5 (Figure 10). With these parameters, the loss in $\mathrm{Pd}$ is $1,5 \%$, and the $\mathrm{Pd}$ purity in the organic phase is over $99,5 \%\left(99,7 \%\right.$ Fe scrubbing). The $\mathrm{HNO}_{3}$ concentration in the organic phase decreases regularly along the stages, so that at final stage, the organic phase is equilibrated with a $1,8 \mathrm{M}$ aqueous $\mathrm{HNO}_{3}$ solution. At this point, $\mathrm{DFe}=$ 0,008, and $\mathrm{S}_{\mathrm{Pd} / \mathrm{Fe}}=465$ : the slight decrease in $\mathrm{HNO}_{3}$ content in both phases enables to keep Pd in the solvent with minimal losses, along with a drastic increase in the selectivity regarding $\mathrm{Fe}$, which enables complete scrubbing of Fe from the solvent.

A similar strategy was adopted in order to strip Pd from the organic phase, this time with water. The decrease in $\mathrm{HNO}_{3}$ content in the organic phase is much more pronounced as the distribution coefficient of $\mathrm{HNO}_{3}$ also decreases when the amount $\mathrm{HNO}_{3}$ in the aqueous layer decreases $\left(\left[\mathrm{HNO}_{3}\right]_{\mathrm{aq}}\right.$ is below 2, see Figure 8). Practically, more than $90 \%$ 
of the $\mathrm{HNO}_{3}$ is stripped from the organic layer during the first stage. As a consequence, DPd drops and Pd can be easily stripped from the organic layer within a few stages. The only concern is the stability of the $\mathrm{Pd}(\mathrm{II})$ solution along the different stages: to avoid Pd(II) hydrolysis, we preferred to model the process employing a $5.10^{-2} \mathrm{~mol} / \mathrm{L}$ aqueous $\mathrm{HNO}_{3}$ solution (Figure 11). The results are very similar to stripping with $\mathrm{H}_{2} \mathrm{O}$ only, except that aqueous and organic layers equilibrate so that $\left[\mathrm{HNO}_{3}\right]_{\mathrm{aq}}=5.10^{-2} \mathrm{~mol} / \mathrm{L}$. Pd is quantitatively (more than 99,9\%) stripped from the organic phase after 6 stages, and the final aqueous Pd solution contains ca. $1 \mathrm{~g} / \mathrm{L}$ Pd. At such a concentration aqueous $\mathrm{Pd}(\mathrm{II})$ can be easily processed in order to isolate a salt such as $\mathrm{PdCl}_{2}\left(\mathrm{NH}_{3}\right)_{2}$ after precipitation with ammonium chloride (or ammonia then chlorohydric acid) [43]. Overall, with such a process, starting from an aqueous $\mathrm{HNO}_{3}$ solution containing rather diluted $\mathrm{Pd}(\mathrm{II})$ (100 mg/L) and concentrated Fe(III) (2 g/L), a $1 \mathrm{~g} / \mathrm{L} \mathrm{Pd(II)} \mathrm{aqueous} \mathrm{solution} \mathrm{can} \mathrm{be} \mathrm{easily}$ obtained, with minimal Pd loss (1,5\%), excellent purity (more than 99,5\%), and generation of only $1 / 5^{\text {th }}$ of the initial volume of an aqueous effluent (resulting from $\mathrm{Fe}$ scrubbing), fully compatible with the raffinate for further elimination or possible valuation. Furthermore, the final organic phase does not contain any undesired reagent (specific $\mathrm{Pd}(\mathrm{II})$ chelating agents for instance) that could disturb re-introduction of same solvent in a next extraction step, so that solvent regeneration may be straightforward, even not necessary. The excellent stability of DMDBTDMA regarding aqueous $\mathrm{HNO}_{3}$ may indeed protect from a systematic solvent regeneration.

Although they rapidly revealed possible issues from the extraction step, the use of sulfur based reagents such as BESO or DHS could also be envisioned. However, backextraction of $\mathrm{Pd}(\mathrm{II})$ from solvents based on these reagents requires the use of a specific aqueous layer containing a $\mathrm{Pd}(\mathrm{II})$ stabilizing agent (ammonia, thiourea, thiocyanate...). The switch from nitrate media to other media generally leads to the generation of more 
aqueous effluents, as solvent needs to be washed and re-equilibrated with $\mathrm{HNO}_{3}$ afterwards prior to re-employment in the extraction step. Although we did not investigate in detail these steps with the same parameters employed in the proposed process modelling, it remains certain that the malonamide based process is the more straightforward and simplest which can be envisioned.

\section{CONCLUSION}

During this work, the efficiency and selectivity of Pd(II) extraction with DMDOHEMA and DMDBTDMA based organic solvents from nitric media have been characterized in detail. Excellent selectivity regarding metallic cations commonly found in various wastes has been demonstrated. The only problematic cation encountered is $\mathrm{Fe}(\mathrm{III})$, as the $\mathrm{Pd}(\mathrm{II})$ selectivity regarding this cation drops below 50 when a sufficient $\mathrm{Pd}(\mathrm{II})$ distribution coefficient is desired. However, a process based on extraction of Pd(II) with some Fe(III),

15 followed by $\mathrm{Fe}(\mathrm{III})$ scrubbing with diluted aqueous $\mathrm{HNO}_{3}$ is easily conceivable. The use of 0,6 M DMDBTDMA in toluene was demonstrated to be efficient after modelling of a simple counter-current process. Furthermore, such a process does neither generate extensive aqueous effluents, nor require extra specific Pd chelating reagents. These results are of great importance as these parameters are too often neglected during the studies of new extraction solvents. Overall, the efficiency of malonamides regarding Pd isolation and purification is excellent in regard with common reagents regularly considered for further processing of aqueous wastes containing Pd. Further studies will be devoted to the processing of available wastes and dedicated to the re-employment of the solvent, including long term stability studies of the malonamides in the process. 


\section{FIGURES}

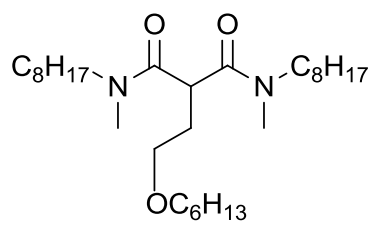

DMDOHEMA

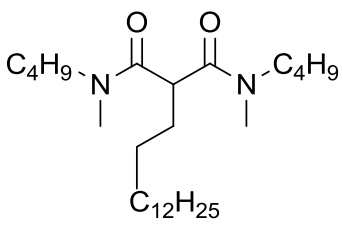

DMDBTDMA

Figure 1. Structure of malonamides employed for Pd(II) extraction.

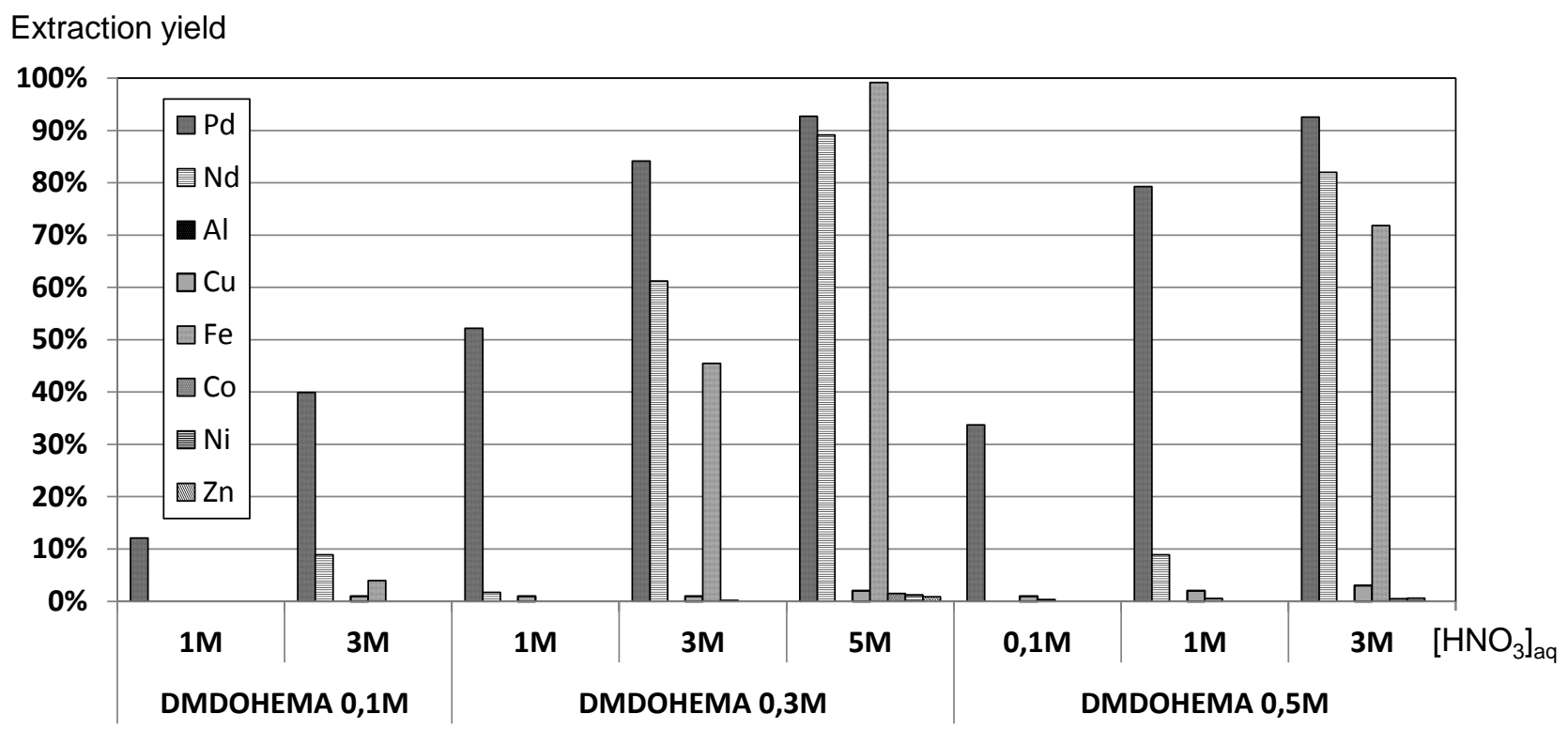

Figure 2. Extraction yields of various metallic cations with DMDOHEMA in $n$-heptane according to extractant concentration in solvent and aqueous $\mathrm{HNO}_{3}$ concentration. Initial metal concentration $100 \mathrm{mg} / \mathrm{L}$ (for each cation), aqueous/organic phase volume ratio $1,1 \mathrm{~h}$ extraction. 

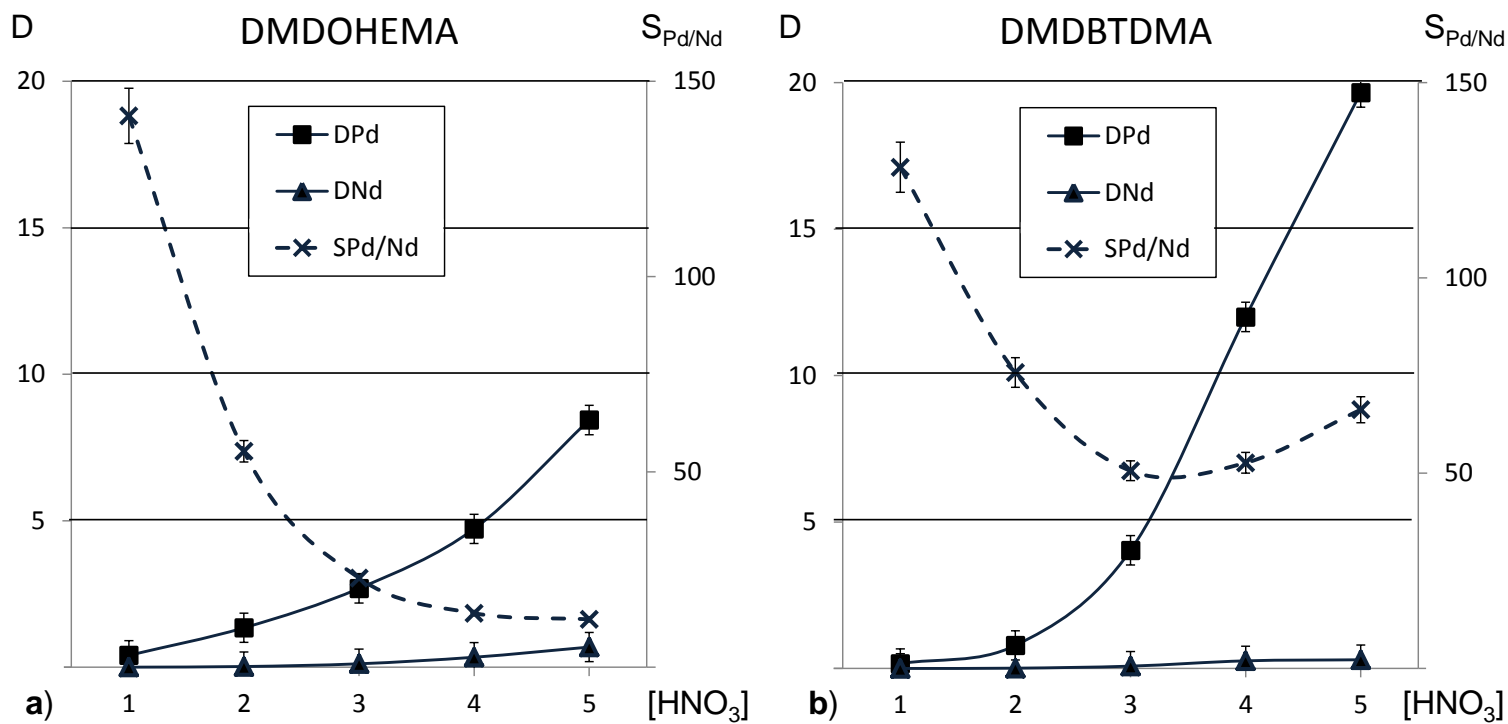

Figure 3. Distribution ratio of $\mathrm{Pd}(\mathrm{II})$ (DPd) and $\mathrm{Nd}(\mathrm{III})$ (DNd), along with $\mathrm{Pd} / \mathrm{Nd}$ selectivity $\left(\mathrm{S}_{\mathrm{Pd} / \mathrm{Nd}}\right)$ after extraction with DMDOHEMA or DMDBTDMA in toluene. Extractant concentration $0,3 \mathrm{~mol} / \mathrm{L}$, initial $[\mathrm{Pd}]_{\mathrm{aq}} 100 \mathrm{mg} / \mathrm{L}$, initial $[\mathrm{Nd}]_{\mathrm{aq}} 400 \mathrm{mg} / \mathrm{L}$, aqueous/organic phase volume ratio 1 , $5 \quad 1$ h extraction. 


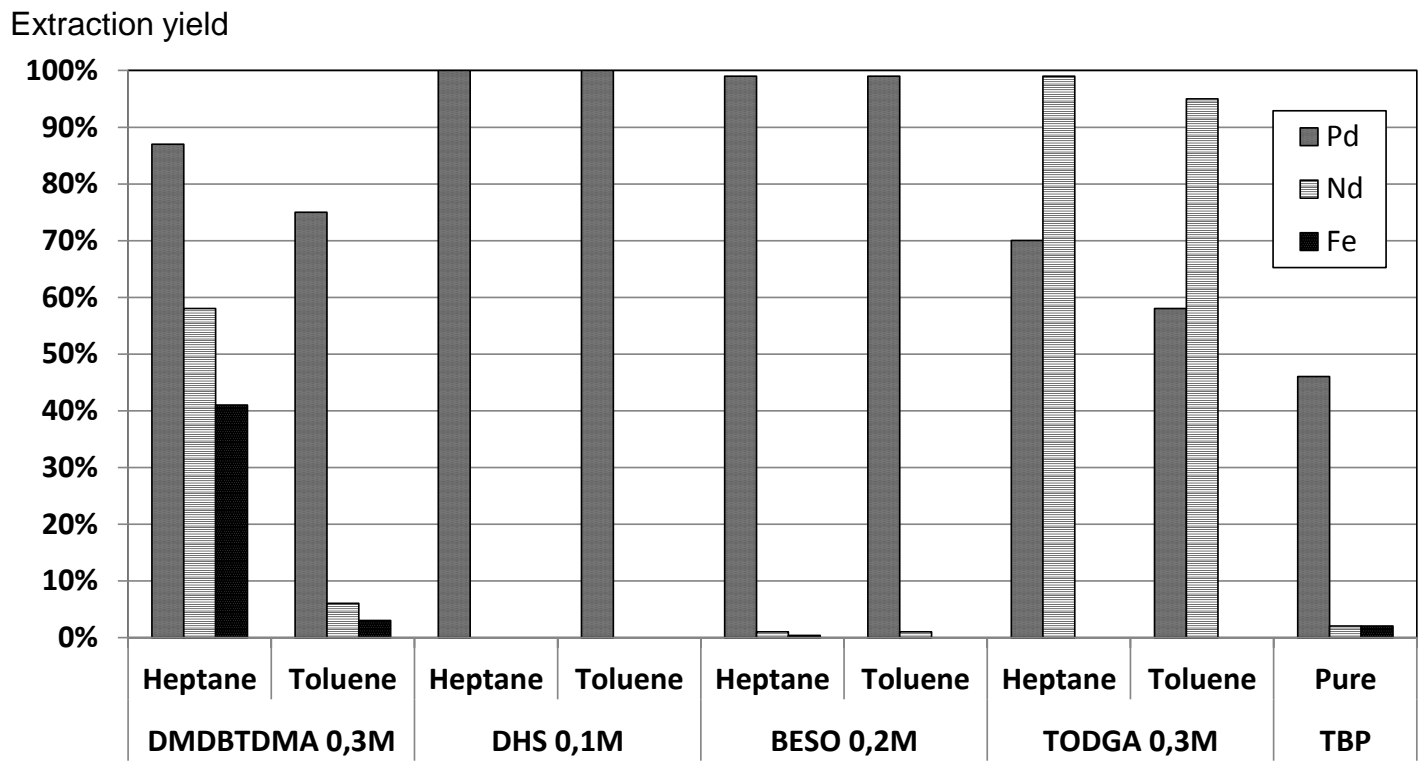

Figure 4. Extraction yields of $\mathrm{Pd}(\mathrm{II}), \mathrm{Nd}(\mathrm{III})$ and $\mathrm{Fe}(\mathrm{III})$ with different solvents. Initial $[\mathrm{Pd}]_{\mathrm{aq}} 100$ $\mathrm{mg} / \mathrm{L}$, initial $[\mathrm{Nd}]_{\mathrm{aq}} 200 \mathrm{mg} / \mathrm{L}$, initial $[\mathrm{Fe}]_{\mathrm{aq}} 500 \mathrm{mg} / \mathrm{L},\left[\mathrm{HNO}_{3}\right]_{\mathrm{aq}} 3 \mathrm{~mol} / \mathrm{L}$, aqueous/organic phase volume ratio $1,1 \mathrm{~h}$ extraction. 


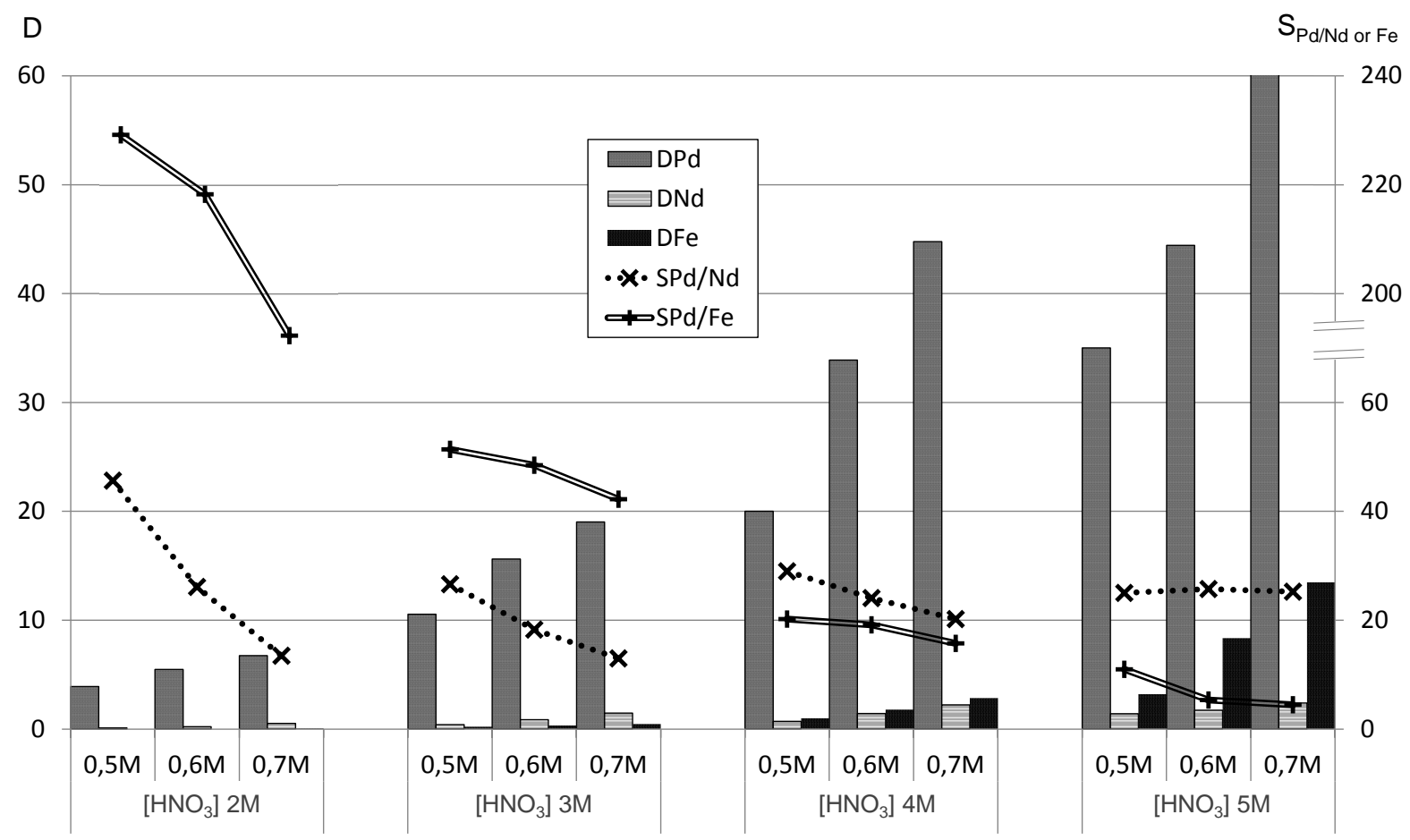

Figure 5. Distribution ratio of $\mathrm{Pd}(\mathrm{II})(\mathrm{DPd}), \mathrm{Nd}(\mathrm{III})$ (DNd) and $\mathrm{Fe}(\mathrm{III})(\mathrm{DFe})$, along with $\mathrm{Pd} / \mathrm{Nd}$ $\left(\mathrm{S}_{\mathrm{Pd} / \mathrm{Nd}}\right)$ and $\mathrm{Pd} / \mathrm{Fe}\left(\mathrm{S}_{\mathrm{Pd} / \mathrm{Fe}}\right)$ selectivity after extraction with DMDBTDMA in toluene. Extractant concentration $0,5-0,7 \mathrm{~mol} / \mathrm{L}$, initial $[\mathrm{Pd}]_{\mathrm{aq}} 200 \mathrm{mg} / \mathrm{L}$, initial $[\mathrm{Nd}]_{\mathrm{aq}} 1000 \mathrm{mg} / \mathrm{L}$, initial $[\mathrm{Fe}]_{\mathrm{aq}} 1000$ $\mathrm{mg} / \mathrm{L}$, aqueous/organic phase volume ratio $1,1 \mathrm{~h}$ extraction. 


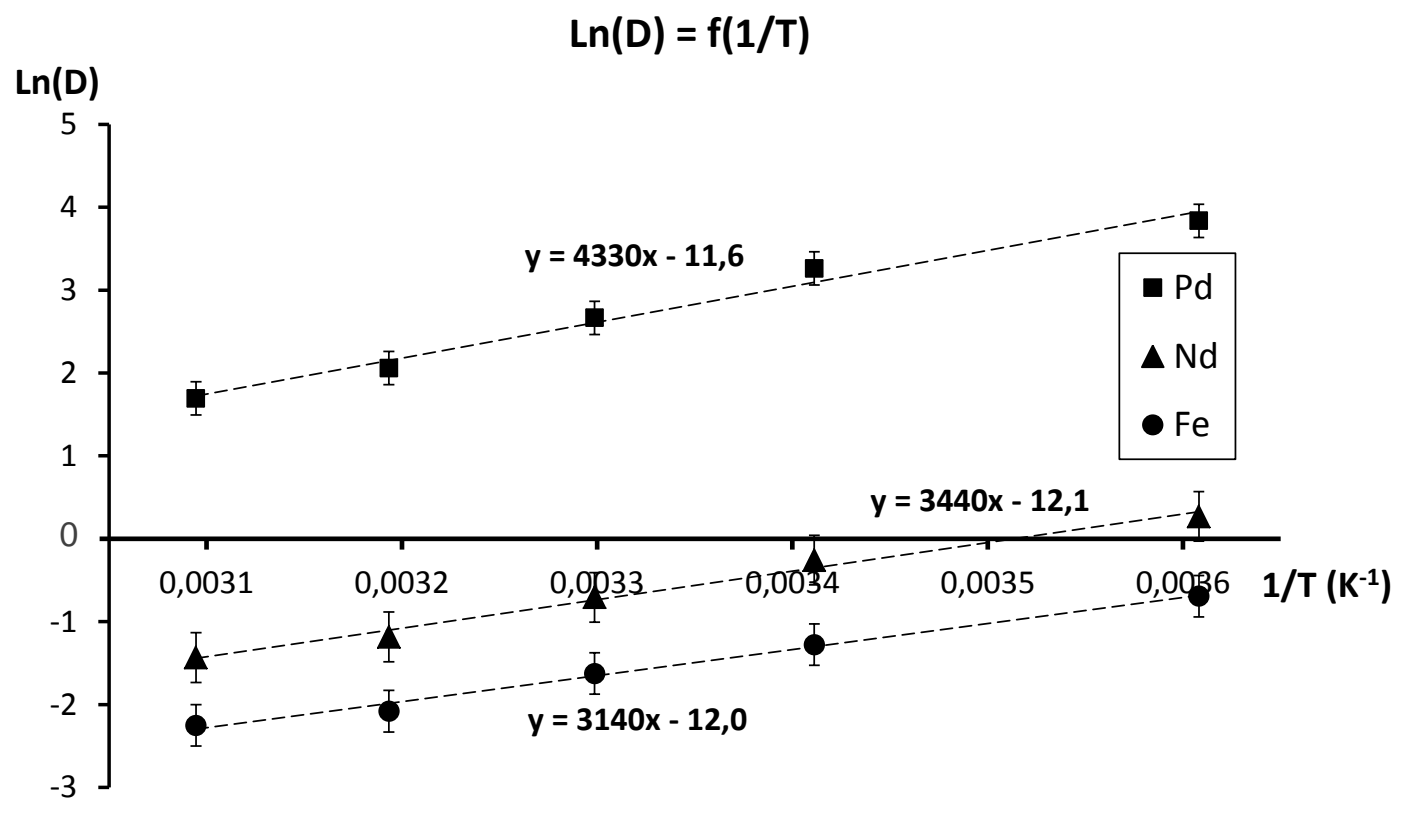

Figure 6. Distribution ratio of $\mathrm{Pd}(\mathrm{II}), \mathrm{Nd}(\mathrm{III})$ and $\mathrm{Fe}(\mathrm{III})$ after extraction with $0,6 \mathrm{~mol} / \mathrm{L}$ DMDBTDMA in toluene according to $1 / \mathrm{T}$. Initial $[\mathrm{Pd}]_{\mathrm{aq}} 100 \mathrm{mg} / \mathrm{L}$, initial $[\mathrm{Nd}]_{\mathrm{aq}} 200 \mathrm{mg} / \mathrm{L}$, initial $[\mathrm{Fe}]_{\mathrm{aq}} 200 \mathrm{mg} / \mathrm{L},\left[\mathrm{HNO}_{3}\right]_{\mathrm{aq}} 3 \mathrm{~mol} / \mathrm{L}$, aqueous/organic phase volume ratio $1,1 \mathrm{~h}$ extraction. 


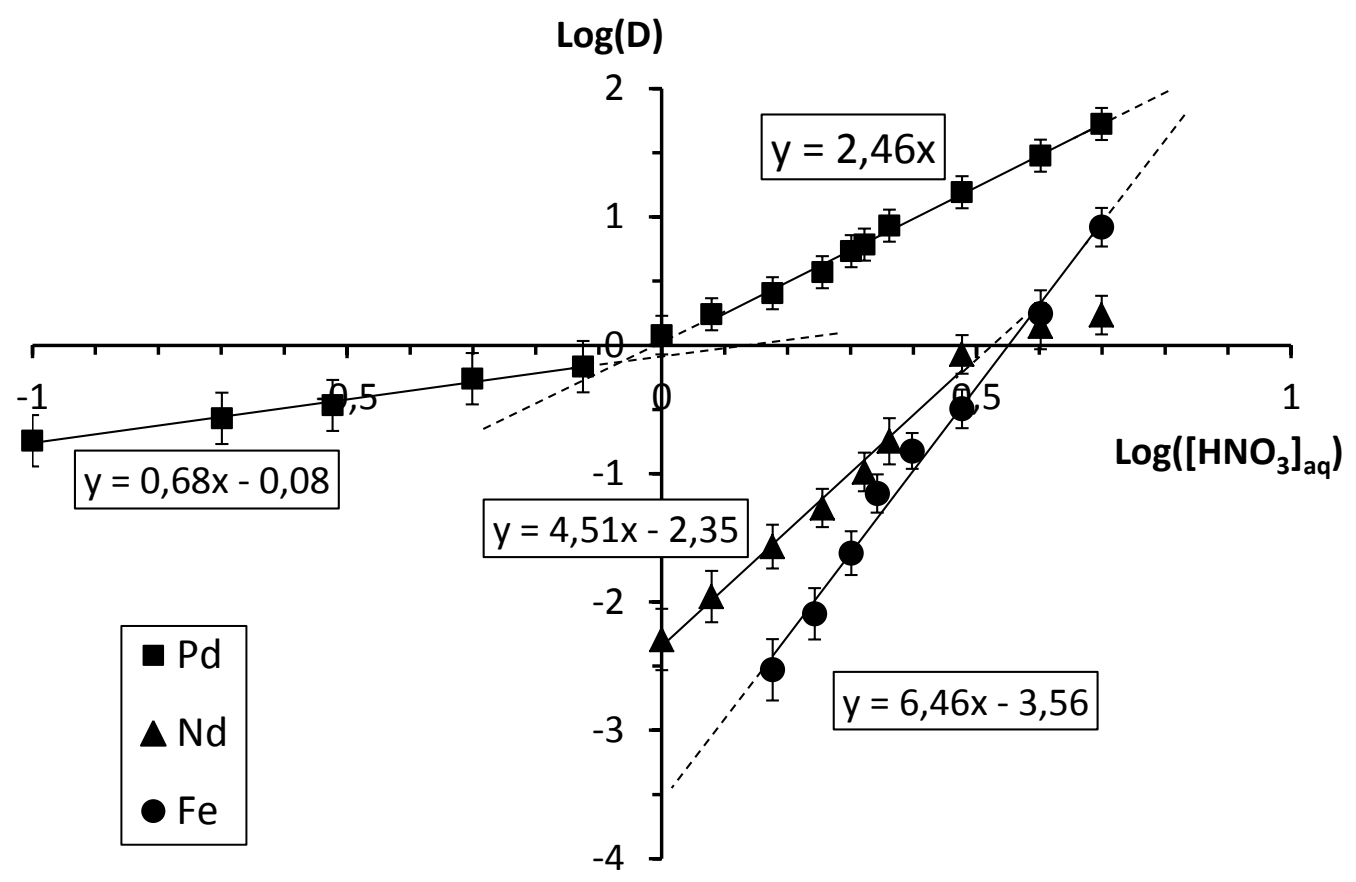

Figure 7. Distribution ratio of $\mathrm{Pd}(\mathrm{II}), \mathrm{Nd}(\mathrm{III})$ and $\mathrm{Fe}(\mathrm{III})$ after extraction with $0,6 \mathrm{~mol} / \mathrm{L}$ DMDBTDMA in toluene according to aqueous $\mathrm{HNO}_{3}$ concentration. Initial $[\mathrm{Pd}]_{\mathrm{aq}} 200 \mathrm{mg} / \mathrm{L}$, initial $[\mathrm{Nd}]_{\mathrm{aq}} 500 \mathrm{mg} / \mathrm{L}$, aqueous/organic phase volume ratio 1, initial $[\mathrm{Fe}]_{\mathrm{aq}} 2000 \mathrm{mg} / \mathrm{L}$, aqueous/organic phase volume ratio $0,5,1 \mathrm{~h}$ extraction. 


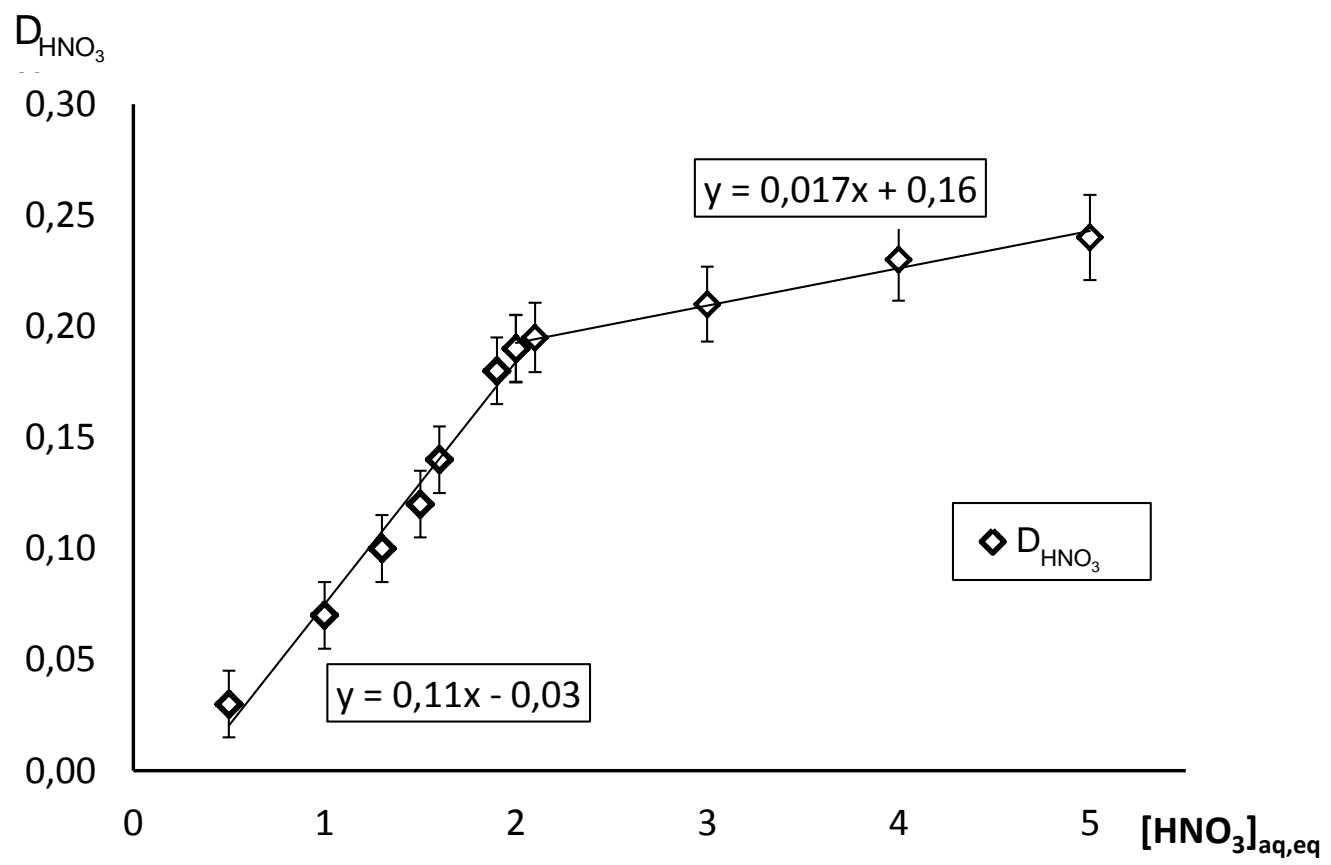

Figure 8. Distribution ratio of $\mathrm{HNO}_{3}$ after extraction with 0,6 mol/L DMDBTDMA in toluene according to aqueous $\mathrm{HNO}_{3}$ concentration. Aqueous/organic phase volume ratio $1,1 \mathrm{~h}$ extraction. 


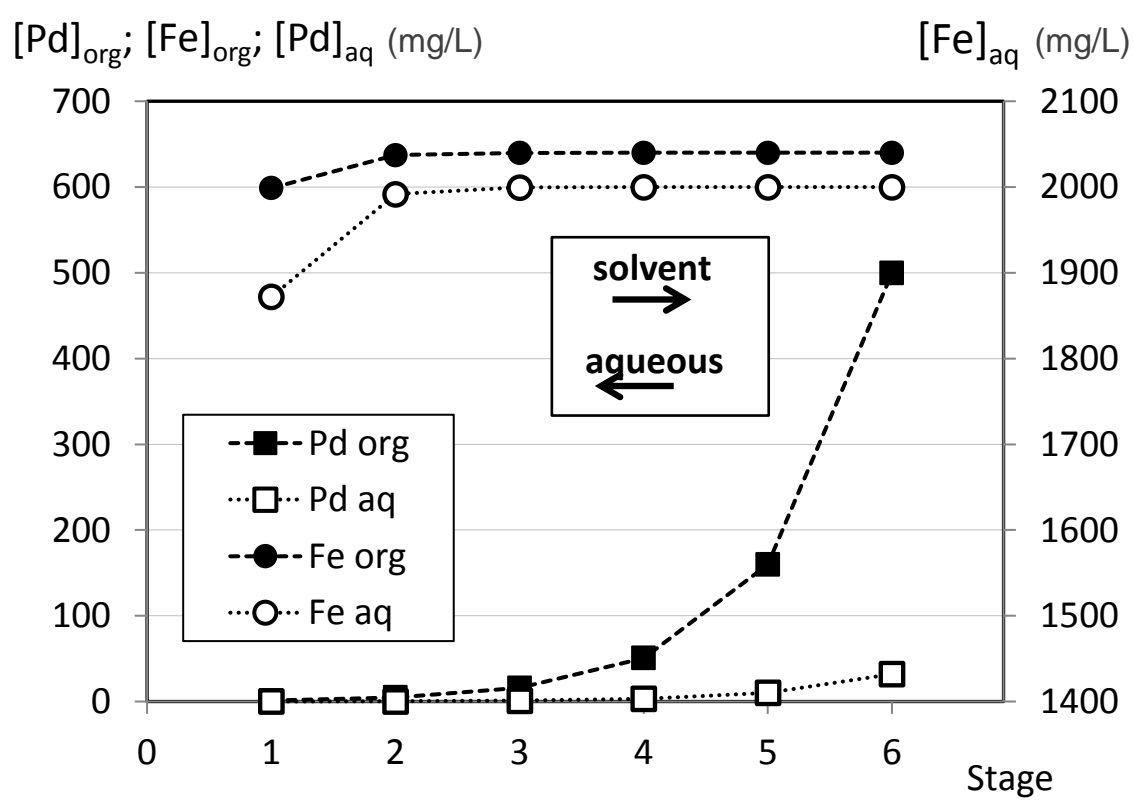

Figure 9. Modelling of a six-stage counter-current extraction of an aqueous phase (initial $[\mathrm{Pd}]_{\mathrm{aq}}$ $100 \mathrm{mg} / \mathrm{L}$, initial $[\mathrm{Fe}]_{\mathrm{aq}} 2000 \mathrm{mg} / \mathrm{L},\left[\mathrm{HNO}_{3}\right] 3 \mathrm{~mol} / \mathrm{L}$ ) with $0,6 \mathrm{~mol} / \mathrm{L}$ DMDBTDMA in toluene. Aqueous/organic phase flow ratio 5, distribution ratio at equilibrium $\mathrm{DPd}=15,6$ and $\mathrm{DFe}=0,32$. 


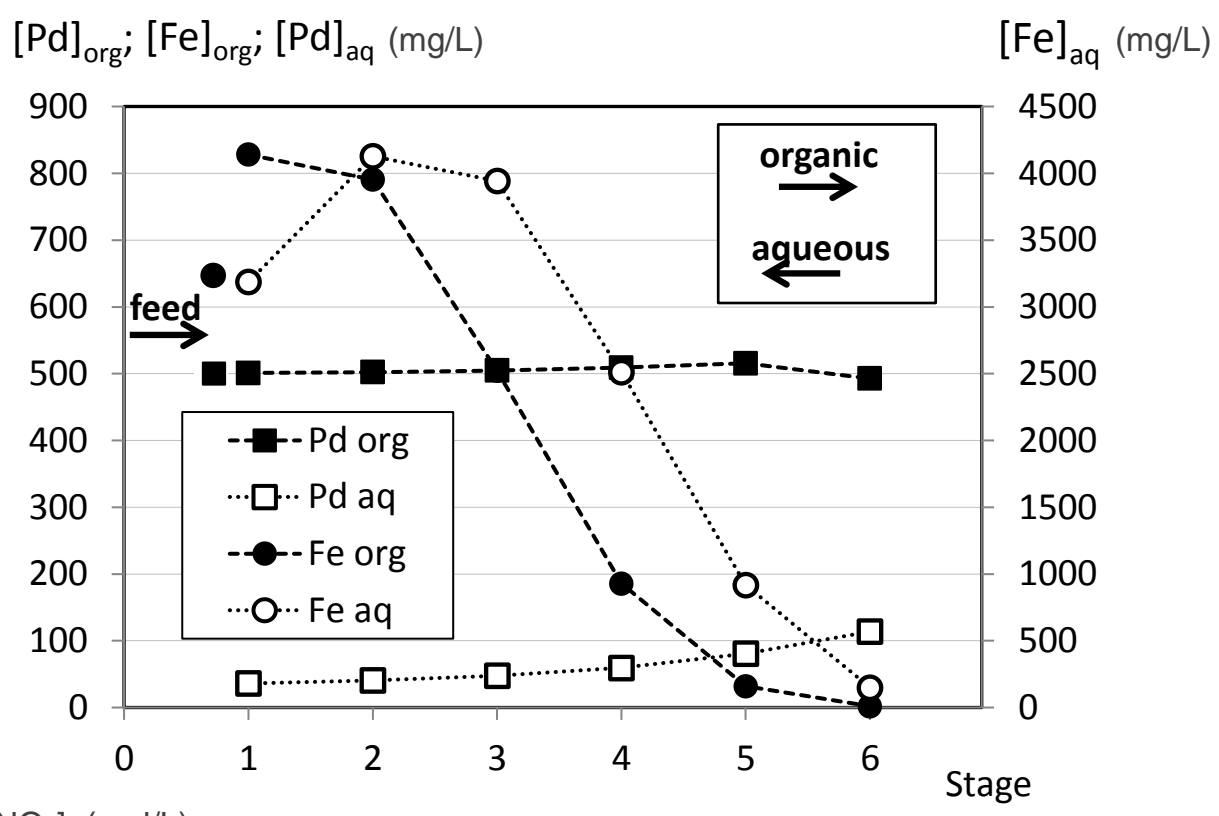

$\left[\mathrm{HNO}_{3}\right](\mathrm{mol} / \mathrm{L})$

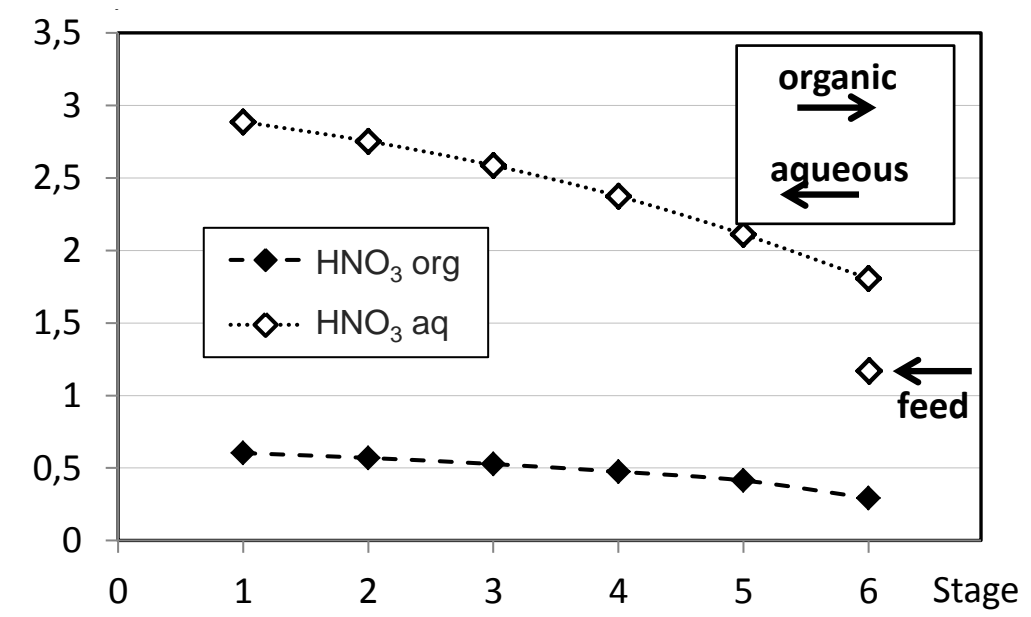

Figure 10. Modelling of a six-stage counter-current Fe scrubbing of an organic phase $(0,6 \mathrm{~mol} / \mathrm{L}$ DMDBTDMA in toluene, initial [Pd $]_{\text {org }} 500 \mathrm{mg} / \mathrm{L}$, initial $[\mathrm{Fe}]_{\text {org }} 640 \mathrm{mg} / \mathrm{L}$, initial $\left[\mathrm{HNO}_{3}\right]_{\text {org }} 0,63$ $\mathrm{mol} / \mathrm{L}$ ) with an aqueous $1,2 \mathrm{~mol} / \mathrm{L} \mathrm{HNO}_{3}$ solution. Organic/aqueous phase flow ratio $5, \mathrm{HNO}_{3}$ distribution ratio $\mathrm{DHNO}_{3}$ fitted in order to comply with equation depicted on Fig. 8, Pd and Fe distribution ratio DPd and DFe considered at equilibrium and calculated according to equations depicted on Fig. 7. 

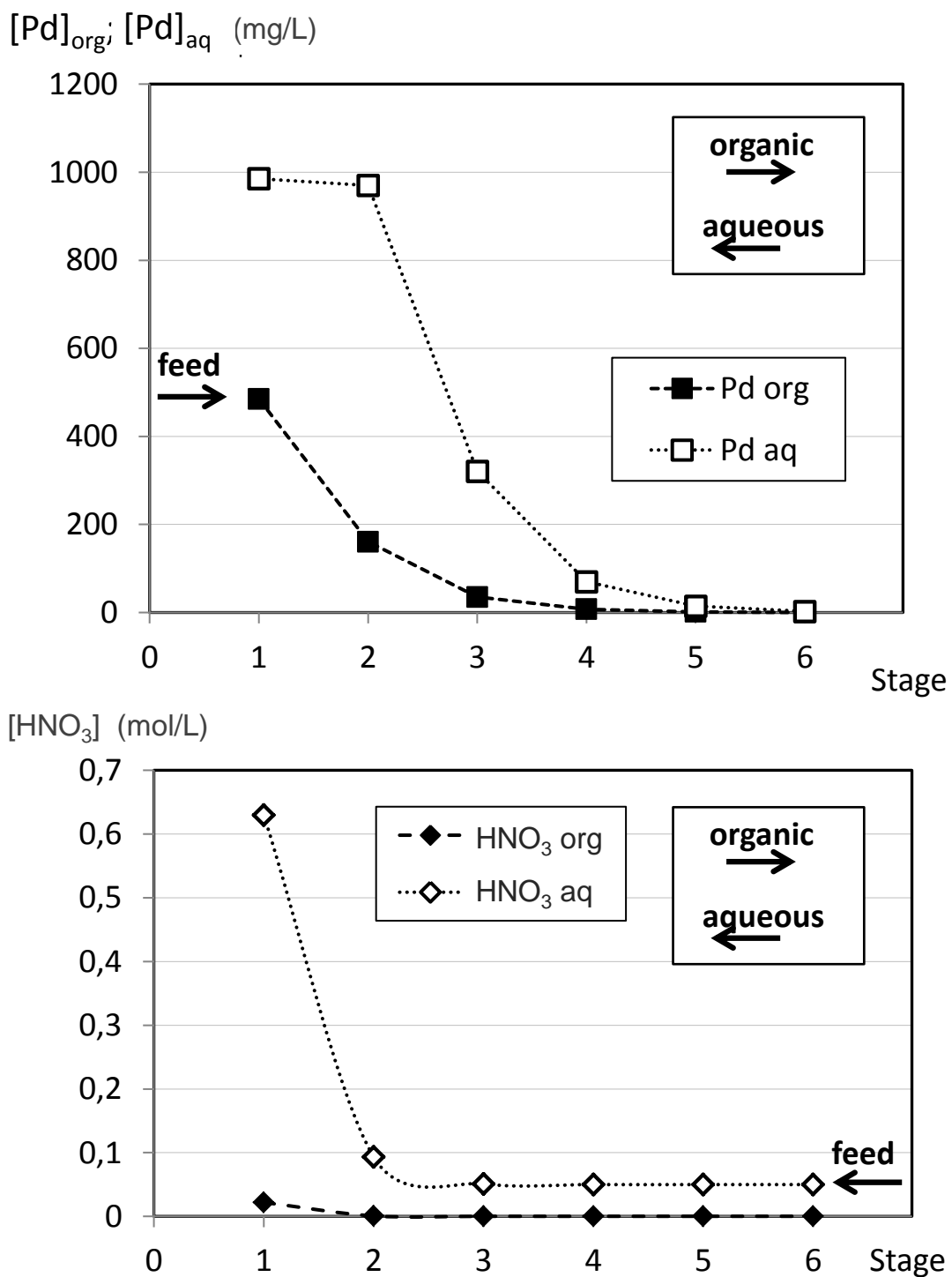

Figure 11. Modelling of a six-stage counter-current Pd stripping of an organic phase $(0,6 \mathrm{~mol} / \mathrm{L}$ DMDBTDMA in toluene, initial [Pd $]_{\text {org }} 493 \mathrm{mg} / \mathrm{L}$, initial $\left[\mathrm{HNO}_{3}\right]_{\text {org }} 0,29 \mathrm{~mol} / \mathrm{L}$ ) with an aqueous $5.10^{-2} \mathrm{~mol} / \mathrm{L} \mathrm{HNO}_{3}$ solution. Organic/aqueous phase flow ratio $2, \mathrm{HNO}_{3}$ distribution ratio $\mathrm{DHNO}_{3}$ fitted in order to comply with equation depicted on Fig. 8, Pd distribution ratio Dpd considered at equilibrium and calculated according to equations depicted on Fig. 7. 
TABLES

Table 1. Quantification limits (LoQ) for ICP-AES analysis.

\begin{tabular}{l|cccccccc}
\hline Metal & $\boldsymbol{A l}$ & $\boldsymbol{C o}$ & $\boldsymbol{C u}$ & $\boldsymbol{F e}$ & $\boldsymbol{N i}$ & Nd & $\boldsymbol{P d}$ & $\mathrm{Zn}$ \\
\hline $\operatorname{LoQ}(\mathrm{mg} / \mathrm{L})$ & 0,24 & 0,17 & 0,07 & 0,21 & 0,15 & 0,23 & 0,28 & 0,26 \\
\hline
\end{tabular}

5

Table 2. $\mathrm{Pd}(\mathrm{II})$ distribution coefficient (DPd) and $\mathrm{Pd}(\mathrm{II}) / \mathrm{Nd}(\mathrm{III})$ selectivity $\left(\mathrm{S}_{\mathrm{Pd} / \mathrm{Nd}}\right)$ in selected conditions with DMDOHEMA based solvents.

\begin{tabular}{|c|c|c|c|c|c|c|c|c|}
\hline \multirow{2}{*}{$\begin{array}{l}\text { Conditions } \\
\text { Extraction }\end{array}$} & \multicolumn{2}{|c|}{$\begin{array}{c}0,3 \mathrm{M} \text { in heptane } \\
{\left[\mathrm{HNO}_{3}\right]_{a q}=4 \mathrm{M}}\end{array}$} & \multicolumn{2}{|c|}{$\begin{array}{l}0,5 \mathrm{M} \text { in heptane } \\
{\left[\mathrm{HNO}_{3}\right]_{a q}=3 \mathrm{M}}\end{array}$} & \multicolumn{2}{|c|}{$\begin{array}{l}0,3 \mathrm{M} \text { in toluene } \\
{\left[\mathrm{HNO}_{3}\right]_{a q}=4 \mathrm{M}}\end{array}$} & \multicolumn{2}{|c|}{$\begin{array}{l}0,5 \mathrm{M} \text { in toluene } \\
{\left[\mathrm{HNO}_{3}\right]_{a q}=3 \mathrm{M}}\end{array}$} \\
\hline & DPd & $\mathrm{S}_{\mathrm{Pd} / \mathrm{Nd}}$ & DPd & $\mathrm{S}_{\mathrm{Pd} / \mathrm{Nd}}$ & $D_{P d}$ & $\mathrm{~S}_{\mathrm{Pd} / \mathrm{Nd}}$ & DPd & $\mathrm{S}_{\mathrm{Pd} / \mathrm{Nd}}$ \\
\hline results & 6,4 & 1,8 & 12 & 3,4 & 4,9 & 13,8 & 9,3 & 21 \\
\hline
\end{tabular}

Table 3. Results from solvent scrubbing with $\mathrm{H}_{2} \mathrm{O}$ or $1 \mathrm{M} \mathrm{HNO}_{3}$ : Pd loss, Fe elimination, and final aqueous $\mathrm{HNO}_{3}$ concentration. Initial organic phase: DMDBTMA 0,6 $\mathrm{M}$ in toluene equilibrated with $3 \mathrm{M}$ aqueous $\mathrm{HNO}_{3}$ and containing $95 \mathrm{mg} / \mathrm{L} \mathrm{Pd}(\mathrm{II})$ and $80 \mathrm{mg} / \mathrm{L} \mathrm{Fe}(\mathrm{III})$.

\begin{tabular}{|c|c|c|c|c|c|c|c|c|c|}
\hline \multirow{2}{*}{$\begin{array}{c}\text { Conditions } \\
\text { Scrubbing }\end{array}$} & \multicolumn{3}{|c|}{$\begin{array}{c}\text { Stripping with } \mathrm{H}_{2} \mathrm{O}, \\
\qquad / \mathrm{A}=5 / 1\end{array}$} & \multicolumn{3}{|c|}{$\begin{array}{c}\text { Stripping with } \mathrm{H}_{2} \mathrm{O} \\
\mathrm{O} / \mathrm{A}=10 / 1\end{array}$} & \multicolumn{3}{|c|}{$\begin{array}{c}\text { Stripping with } 1 \mathrm{M} \mathrm{HNO}_{3}, \\
\qquad / A=5 / 1\end{array}$} \\
\hline & Pd loss & Fe elim & {$\left[\mathrm{HNO}_{3}\right]_{\mathrm{aq}}$} & Pd loss & Fe elim. & {$\left[\mathrm{HNO}_{3}\right]_{\mathrm{aq}}$} & Pd loss & Fe elim. & {$\left[\mathrm{HNO}_{3}\right]_{\mathrm{aq}}$} \\
\hline results & $5,2 \%$ & $94 \%$ & $1,7 \mathrm{M}$ & $1,1 \%$ & $70 \%$ & $2,4 \mathrm{M}$ & $2,3 \%$ & $88 \%$ & $2,4 \mathrm{M}$ \\
\hline
\end{tabular}




\section{REFERENCES}

[1] Işıldar, A.; Rene, E.R.; Hullebusch, E.D. Electronic waste as a secondary source of critical metals: management and recovery technologies. Resour. Conserv. Recycl. 2018, 135, 296-312. DOI: 10.1016/j.resconrec.2017.07.031.

[2] Wang, M.; Tan, Q.; Chiang, J.F.; Li, J. Recovery of rare and precious metals from urban mines-A review. Front. Environ. Sci. Eng. 2017, 11:1. DOI: 10.1007/s11783-0170963-1.

[3] Jin, Y.; Kim, J.; Guillaume, B. Review of critical material studies. Resour. Conserv. Recycl. 2016, 113, 77-87. DOI: 10.1016/j.resconrec.2016.06.003.

[4] Zhang, Z.; Zhang, F.S. Selective recovery of palladium from waste printed circuit boards by a novel non-acid process. J. Hazard. Mater. 2014, 279, 46-51. DOI: 10.1016/j.jhazmat.2014.06.045.

[5] Kaya, M. Recovery of metals and nonmetals from electronic waste by physical and

15 chemical recycling processes. Waste Manag. 2016, 57, 64-90. DOI: 10.1016/j.wasman.2016.08.004.

[6] Sobral, L.G.S.; Granato, M. Palladium: Extraction and Refining. Min. Eng. 1992, 5, $17-25$.

[7] Nogueira, C.A.; Paiva, A.P.; Oliveira, P.C.; Costa, M.C.; da Costa, A.M. Oxidative 20 leaching process with cupric ion in hydrochloric acid media for recovery of $\mathrm{Pd}$ and $\mathrm{Rh}$ from spent catalytic converters. J. Hazard. Mater. 2014, 278, 82-90. DOI: 10.1016/j.jhazmat.2014.05.099.

[8] Fernandes, T.A.; Kurhe, D.K.; Chavan, A.A.; Jayaram, R.V. Recovery and reuse of palladium from spent glucometer electrochemical test strips. Hydrometallurgy 2016, 165, 199-205. DOI: 10.1016/j.hydromet.2015.09.002. 
[9] Kinoshita, T.; Akita, S.; Kobayashi, N.; Nii, S.; Kawaizumi, F.; Takahashi, K. Metal recovery from non-mounted printed wiring boards via hydrometallurgical processing. Hydrometallurgy, 2003, 69, 73-79. DOI: 10.1016/S0304-386X(03)00031-8.

[10] Sheng, P.P.; Etsell, T.H. Recovery of gold from computer circuit board scrap using aqua regia. Waste Manage. Res. 2007, 25, 380-383. DOI: 10.1177/0734242X07076946.

[11] Cayumil, R.; Khanna, R.; Rajarao, R.; Mukherjee, P.S.; Sahajwalla, V. Concentration of precious metals during their recovery from electronic waste. Waste Manag. 2016, 57, 121-130. DOI: 10.1016/j.wasman.2015.12.004.

[12] Nguyen, T.H.; Wang, L.; Lee, M.S. Separation and Recovery of Precious Metals from Leach Liquors of Spent Electronic Wastes by Solvent Extraction. Korean J. Met. Mater. 2017, 55, 247-255. DOI: 10.3365/KJMM.2017.55.4.247.

[13] Prabaharan, G.; Barik, S.P.; Kumar, B. A hydrometallurgical process for recovering total metal values from waste monolithic ceramic capacitors. Waste Manag. 2016, 52, 302-308. DOI: 10.1016/j.wasman.2016.04.010.

[14] Karwowska, E.; Andrzejewska-Morzuch, D.; Łebkowska, M.; Tabernacka, A.; Wojtkowska, M.; Telepko, A.; Konarzewska, A. Bioleaching of metals from printed circuit boards supported with surfactant-producing bacteria. J. Hazard. Mater. 2014, 264, 203-210. DOI: 10.1016/j.jhazmat.2013.11.018.

[15] Jung, B.H.; Park, Y.Y.; An, J.W.; Kim, S.J.; Tran, T.; Kim, M.J. Processing of high purity gold from scraps using diethylene glycol di-N-butyl ether. Hydrometallurgy 2009, 95, 262-266. DOI: 10.1016/j.hydromet.2008.06.006.

[16] Yi, Q.; Fan, R.; Xie, F.; Min, H.; Zhang, Q.; Luo, Z. Selective Recovery of Au(III) and Pd(II) from Waste PCBs Using Ethylenediamine Modified Persimmon Tannin Adsorbent. Proc. Environ. Sci. 2016, 3, 185-194. DOI: 10.1016/j.proenv.2016.02.025. 
[17] Kolarik, Z.; Renard, E.V. Recovery of value fission platinoids from spent nuclear fuel - Part I: General Considerations and Basic Chemistry Platinum Metals Rev. 2003, $47,74-87$.

[18] Charlesworth, P. Separating the Platinum Group Metals by Liquid-Liquid Extraction. Platinum Metals Rev. 1981, 25, 106-112.

[19] Moon, J.; Nishihama, S.; Yoshizuka, K. Recovery of Platinum and Palladium from Spent Automobile Catalyst by Solvent-Impregnated Resins, Solvent Extr. Ion Exch. 2018, in press. DOI: 10.1080/07366299.2018.1527806

[20] Gurung, M.; Adhikari, B.B.; Alam, S.; Kawakita, H.; Ohto, K.; Inoue, K. Persimmon tannin-based new sorption material for resource recycling and recovery of precious metals. Chem. Eng. J. 2013, 228, 405-414. DOI: 10.1016/j.cej.2013.05.011. [21] Venkatesan, K.A.; Selvan, R.; Antony, M.P.; Srinivasan, T.G.; Vasudeva Rao, P.R. Extraction of palladium (II) from nitric acid medium by imidazolium nitrate immobilized resin. Hydrometallurgy, 2007, 86, 221-229. DOI: 10.1016/j.hydromet.2006.11.006.

[22] Poirot, R.; Bourgeois, D.; Meyer, D. Palladium Extraction by a Malonamide Derivative (DMDOHEMA) from Nitrate Media: Extraction Behavior and Third Phase Characterization. Solvent Extr. Ion Exch. 2014, 32, 529-542. DOI: 10.1080/07366299.2014.908587.

[23] Poirot, R.; Le Goff, X.; Diat, O.; Bourgeois, D.; Meyer, D. Metal Recognition Driven by Weak Interactions: A Case Study in Solvent Extraction. ChemPhysChem 2016, 17, 2112-2117. 10.1002/cphc.201600305.

[24] Malik, P.; Paiva, A.P. A Novel Solvent Extraction Route for the Mutual Separation of Platinum, Palladium, and Rhodium in Hydrochloric Acid Media. Solvent Extr. Ion Exch. 2010, 28, 49-72. DOI: 10.1080/07366290903408599. 
[25] Costa, M.C.; Pêczek, I.; Sadowski, Z.; Natu, S.; Paiva, A.P. The solvent extraction of iron(III) from chloride solutions by $\mathrm{N}, \mathrm{N}^{\prime}$-tetrasubstituted malonamides: structureactivity relationships. Solvent Extr. Ion Exch. 2007, 25, 463-484. DOI: 10.1080/07366290701415952.

[26] Costa, M.C.; Carvalho, A.; Uryga, A.; Paiva, A.P. Solvent extraction of iron(III) from hydrochloric acid solutions using $\mathrm{N}, \mathrm{N}^{\prime}$-dimethyl-N,N'-diphenylmalonamide and N,N'-dimethyl-N,N'-diphenyltetradecylmalonamide. Solvent Extr. Ion Exch. 2003, 21, 653-686. DOI: 10.1081/SEI-120024550.

[27] Modolo, G.; Vijgen, H.; Serrano-Purroy, D.; Christiansen, B.; Malmbeck, R.; Sorel,

10 C.; Baron, P. DIAMEX Counter-Current Extraction Process for Recovery of Trivalent Actinides from Simulated High Active Concentrate. Sep. Sci. Technol. 2007, 42, 439452. DOI: $10.1080 / 01496390601120763$.

[28] Facchini, A.; Amato, L.; Modolo, G.; Nannicini, R.; Madic, C.; Baron, P. Transientand Steady-State Concentration Profiles in a DIAMEX-like Countercurrent Process for An(III) + Ln(III). Sep. Sci. Technol. 2000, 35, 1055-1068. DOI: 10.1081/SS-100100210. [29] Lumetta, G.J.; Gelis, A.V.; Vandegrift, G.F. Review: Solvent Systems Combining Neutral and Acidic Extractants for Separating Trivalent Lanthanides from the Transuranic Elements. Solvent Extr. Ion Exch. 2010, 28, 287-312. DOI: $10.1080 / 07366291003684253$.

[30] Kolarik, Z.; Renard, E.V. Recovery of value fission platinoids from spent nuclear fuel - Part II: Separation processes. Platinum Metals Rev. 2003, 47, 123-131.

[31] Edwards, J.D.; Colton, D.F.; Lea, R.K. Process for the extraction of precious metals from solutions thereof. European Patent Application 1982, EP0049567, priority 05.09.1980. 
[32] Shukla, J.P.; Singh, R.K.; Sawant, S.R.; Varadarajan, N. Liquid-liquid extraction of palladium(II) from nitric acid by bis(2-ethylhexyl) sulphoxide. Anal. Chim. Acta 1993, 276, 181-187. DOI: 10.1016/0003-2670(93)85054-N.

[33] Kennedy, D.C.; Fritz, J.S. Sulphoxides as solvating reagents for the separation of metal ions, Talanta 1970, 17, 823-835. DOI: 10.1016/0039-9140(70)80176-X.

[34] Preston, J.S.; du Preez, A.C. Solvent extraction of platinum-group metals from hydrochloric acid solutions by dialkyl sulphoxides. Solvent Extr. Ion Exch. 2002, 20, 359-374. DOI: 10.1081/SEI-120004810

[35] Ruhela, R. Separation of Palladium from High Level Liquid waste-A Review. RSC Adv. 2014, 4, 24344-24350. DOI: 10.1039/C4RA02024C.

[36] Whittaker, D.; Geist, A.; Modolo, G.; Taylor, R.; Sarsfield, M.; Wilden, A. Applications of Diglycolamide Based Solvent Extraction Processes in Spent Nuclear Fuel Reprocessing, Part 1: TODGA, Solvent Extr. Ion Exch. 2018, 36, 223-256. DOI: 10.1080/07366299.2018.1464269.

[37] Ansari, S.A.; Pathak, P.N.; Manchanda, V.K.; Husain, M.; Prasad, A.K.; Parmar, V.S. N,N,N',N'-Tetraoctyl Diglycolamide (TODGA): A Promising Extractant for Actinide-Partitioning from High-Level Waste (HLW). Solvent Extr. Ion Exch. 2005, 23, 463-479. DOI: 10.1081/SEI-200066296.

[38] Baba, Y.; Eguchi, T.; Inoue, K. Solvent Extraction of Palladium with Dihexyl Sulfide. J. Chem. Eng. Jpn 1986, 19, 361-366.

[39] Rizvi, G.H.; Mathur, J.N.; Murali, M.S.; Iyer, R.H. Recovery of fission product palladium from acidic high level waste solutions. Sep. Sci. Technol. 1996, 31, 1805-1816. DOI: 10.1080/01496399608001011. 
[40] Huang, H.; Huang, C.; Wu, Y.; Ding, S.; Liu, N.; Su, D.; Lv, T. Extraction of palladium(II) from nitric acid solutions with diglycolthioamide. Hydrometallurgy, 2015, 156, 6-11. DOI: 10.1016/j.hydromet.2015.05.002.

[41] Ruhela R.; Sharma, J.N.; Tomar, B.S.; Hubli, R.C., Suri, A.K. Extractive 5 spectrophotometric determination of palladium with $\mathrm{N}, \mathrm{N}, \mathrm{N}^{\prime}, \mathrm{N}^{\prime}$-tetra(2-ethylhexyl)thiodiglycolamide $\quad$ T(2EH)TDGA. $\quad$ Talanta $\quad 2011, \quad 85, \quad 1217-1220 . \quad$ doi: 10.1016/j.talanta.2011.04.067.

[42] Gannaz, B.; Chiarizia, R.; Antonio, M.R.; Hill, C.; Cote, G. Extraction of Lanthanides(III) and Am(III) by Mixtures of Malonamide and Dialkylphosphoric Acid. Solvent Extr. Ion Exch. 2007, 25, 313-337. DOI: 10.1080/07366290701285512.

[43] Bernardis, F.L.; Grant, R.A.; Sherrington, D.C. A review of methods of separation of the platinum-group metals through their chloro-complexes. React. Funct. Polym. 2005, 65, 205-217. DOI: 10.1016/j.reactfunctpolym.2005.05.011. 